\title{
The combination of $\beta$-caryophyllene, baicalin and catechin synergistically suppresses the proliferation and promotes the death of RAW267.4 macrophages in vitro
}

\author{
MASAYOSHI YAMAGUCHI ${ }^{1}$ and ROBERT M. LEVY $^{2}$ \\ ${ }^{1}$ Department of Hematology and Medical Oncology, Emory University School of Medicine, Atlanta, GA 30322; \\ ${ }^{2}$ Department of Clinical Development, Primus Pharmaceuticals, Inc., Scottsdale, AZ 85253, USA
}

Received June 24, 2016; Accepted November 4, 2016

DOI: $10.3892 /$ ijmm.2016.2801

\begin{abstract}
. $\beta$-caryophyllene, which is a constituent of many essential oils, has been known to be a selective agonist of the cannabinoid receptor type-2 and to exert cannabimimetic antiinflammatory effects in animals. The effects of $\beta$-caryophyllene on macrophages have not been investigated to date. This study was undertaken to determine whether $\beta$-caryophyllene exerts suppressive effects on mouse RAW267.4 macrophages in vitro in comparison with other botanical molecules that exert antioxidant and anti-inflammatory effects. The proliferation of RAW267.4 cells was suppressed by culture with $\beta$-caryophyllene (50, 100 and $200 \mu \mathrm{g} / \mathrm{ml}$ of medium) or curcumin (100 and $200 \mu \mathrm{g} / \mathrm{ml})$. Culture with baicalin $(1-200 \mu \mathrm{g} / \mathrm{ml})$ or (+)-catechin $(1-200 \mu \mathrm{g} / \mathrm{ml})$ did not exert an effect on RAW267.4 cells. The combination of $\beta$-caryophyllene ( 1 or $10 \mu \mathrm{g} / \mathrm{ml}$ ) with either curcumin $(1$ or $10 \mu \mathrm{g} / \mathrm{ml})$, baicalin (1 or $10 \mu \mathrm{g} / \mathrm{ml})$ or (+)-catechin $(1$ or $10 \mu \mathrm{g} / \mathrm{ml})$ did not exert any suppressive effects on cell proliferation. Of note, the combination of all three agents, $\beta$-caryophyllene, baicalin and (+)-catechin at the concentration of either 1 or $10 \mu \mathrm{g} / \mathrm{ml}$ was found to exert synergistic suppressive effects on cell proliferation. Moreover, the combination of $\beta$-caryophyllene, baicalin and (+)-catechin synergistically promoted the death of RAW267.4 cells. Such an effect was blocked by culture with caspase- 3 inhibitor. The combination of the three agents decreased the protein levels of Akt, mitogenactivated protein kinase (MAPK) and cyclooxygenase (COX)-1 or -2 . On the whole, this study demonstrates that the combination of $\beta$-caryophyllene, baicalin and (+)-catechin exerts synergistic suppressive effects on macrophages in vitro. This composition may be a useful as an anti-inflammatory treatment strategy.
\end{abstract}

Correspondence to: Dr Masayoshi Yamaguchi, Department of Hematology and Medical Oncology, Emory University School of Medicine, C-5054, 1365 C Clifton Road NE, Atlanta, GA 30322, USA E-mail: yamamasa1155@yahoo.co.jp

Key words: $\beta$-caryophyllene, baicalin, (+)-catechin, curcumin, cell proliferation, apoptosis, RAW267.4 cells, macrophage

\section{Introduction}

Many botanical molecules are known to possess anti-inflammatory and analgesic effects. $\beta$-caryophyllene is a sesquiterpene, which is the essential oil of many medical plants, particularly clove (Syzygium aromaticum), hemp (Cannabis sativa), rosemary (Rosmarinus officinalis), cinnamon and hops (1-4). $\beta$-caryophyllene is natural dietary ingredient found in many edible plants ingested daily, and has been approved as a food additive by the Food and Drug Administration (FDA).

$\beta$-caryophyllene has been known to be a selective agonist of cannabinoid receptor type- 2 and to exert cannabimimetic anti-inflammatory and analgesic effects in animals $(2,4)$ for both acute and chronic pain with inflammation (4-6). The antiinflammatory effects of $\beta$-caryophyllene are not implicated in its inhibitory effects on the production of tumor necrosis factor (TNF)- $\alpha$ and interleukin (IL)- $1 \beta$, that are related to opioid receptors (7). RAW267.4 cells are murine macrophages that produce various inflammatory cytokines, including TNF- $\alpha$ and IL-1 $\beta$ (8). However, the effects of $\beta$-caryophyllene on RAW267.4 macrophages have not been investigated to date, at least to the best of our knowledge.

This study was undertaken to determine whether $\beta$-caryophyllene exerts suppressive effects on mouse RAW267.4 macrophages in vitro. Moreover, we compared the interactive effects of $\beta$-caryophyllene with other botanical molecules, which exert antioxidant and anti-inflammatory effects on mouse RAW267.4 macrophages in vitro. Of note, this study demonstrated that the combination of $\beta$-caryophyllene, baicalin and (+)-catechin at concentrations, which independently did not exert a significant effect on RAW267.4 cells, exerted synergistic suppressive effects on the proliferation and synergistic stimulatory effects on the death of RAW267.4 cells in vitro. To the best of our knowledge, this is the first time that such a finding has been described. This composition of agents may be a potent and useful tool as an anti-inflammatory therapeutic strategy with less toxicity.

\section{Materials and methods}

Materials. Dulbecco's modification of Eagle's medium (DMEM) with $4.5 \mathrm{~g} / 1$ glucose, L-glutamine and sodium pyruvate and 
antibiotics [penicillin and streptomycin (P/S)] were purchased from Corning (Mediatech, Inc., Manassas, VA, USA). Fetal bovine serum (FBS) was from HyClone (Logan, UT, USA). $\beta$-caryophyllene, baicalin, (+)-catechin, curcumin, and $(+)$-aromatic turmerone were obtained from Cayman Chemical (Ann Arbor, MI, USA). TNF- $\alpha$ was obtained from R\&D Systems (Minneapolis, MN, USA). Sodium butyrate, roscovitine, sulforaphane, PD98059, wortmannin, dibucaine, and all other reagents were purchased from Sigma-Aldrich (St. Louis, MO, USA) unless otherwise specified. The caspase-3 inhibitor (Caspase 3/ CPP32 inhibitor W-1, biotin conjugate; Wako Pure Chemical Industries, Ltd., Osaka, Japan) was diluted in phosphatebuffered saline (PBS) and the other reagents were dissolved in $100 \%$ ethanol or dimethyl sulfoxide for use in the experiments.

RAW267.4 cells. Mouse RAW267.4 cells (murine macrophages) were obtained from the American Type Culture Collection (ATCC, Rockville, MD, USA) $(9,10)$.

Cell proliferation assay. The RAW267.4 cells (1x105/ml/well) cells were cultured using a 24-well plate in DMEM containing $10 \%$ FBS and $1 \% \mathrm{P} / \mathrm{S}$ for $1,2,3$ or 7 days in a water-saturated atmosphere containing $5 \% \mathrm{CO}_{2}$ and $95 \%$ air at $37^{\circ} \mathrm{C}$, as previously described (11). The RAW267.4 cells were cultured in DMEM containing $10 \% \mathrm{FBS}$ and $1 \% \mathrm{P} / \mathrm{S}$ in the presence or absence of absence of either the vehicle $(0.1 \%$ ethanol as a final concentration), $\beta$-caryophyllene [1 $(5 \mu \mathrm{M}), 10,50,100$ or $200 \mu \mathrm{g} / \mathrm{ml}$ of medium], baicalin [1 $(2.24 \mu \mathrm{M}), 10,50,100$ or $200 \mu \mathrm{g} / \mathrm{ml}]$, (+)-catechin [1 $(3.45 \mu \mathrm{M}), 10,50,100$ or $200 \mu \mathrm{g} / \mathrm{ml}]$, curcumin [1 $(2.72 \mu \mathrm{M}), 10,50,100$ or $200 \mu \mathrm{g} / \mathrm{ml}]$, or (+)-aromatic turmerone [1 $(4.62 \mu \mathrm{M}), 5,10,25$ or $50 \mu \mathrm{g} / \mathrm{ml}]$ for 3 days. In separate experiments, the RAW267.4 cells were cultured in DMEM containing $10 \%$ FBS and $1 \% \mathrm{P} / \mathrm{S}$ with either the vehicle $(0.1 \%$ ethanol as a final concentration) or mixture of $\beta$-caryophyllene $(10 \mu \mathrm{g} / \mathrm{ml}$ of medium), baicalin $(10 \mu \mathrm{g} / \mathrm{ml})$ and $(+)$-catechin $(10 \mu \mathrm{g} / \mathrm{ml})$ in the presence or absence of either sodium butyrate $(10$ and $100 \mu \mathrm{M})$, roscovitine (10 and $100 \mathrm{nM})$, sulphoraphane (1 and $10 \mathrm{nM})$, dibucaine $(0.1$ or $1 \mu \mathrm{M})$, PD98059 $(1$ or $10 \mu \mathrm{M})$, or wortmannin ( 0.1 or $1 \mu \mathrm{M})$ for 3 days. Following culture, the cells were detached from the culture dishes and counted using the same method as described below in 'Cell counting'.

Cell death assay. The RAW267.4 cells (1x105/ml/well) were cultured using a 24-well plate in DMEM containing 10\% FBS and $1 \% \mathrm{P} / \mathrm{S}$ for 3 days until they reached confluence, as previously described (12), and the cells were then cultured for an additional 2 days in the presence or absence of absence of either the vehicle $(0.1 \%$ ethanol as a final concentration), $\beta$-caryophyllene (1 or $10 \mu \mathrm{g} / \mathrm{ml}$ of medium) and/or baicalin or $(+)$-catechin (1 or $10 \mu \mathrm{g} / \mathrm{ml}$ of medium) with or without caspase-3 inhibitor $(10 \mu \mathrm{M})$. Following culture, the cells were detached from the culture dishes.

Cell counting. Following trypsinization of each culture dish using $0.2 \%$ trpysin plus $0.02 \%$ EDTA in $\mathrm{Ca}^{2+} / \mathrm{Mg}^{2+}$-free PBS for $2 \mathrm{~min}$ at $37^{\circ} \mathrm{C}$, the detached cells from the dish were collected following centrifugation at $150 \mathrm{x}$ g for $5 \mathrm{~min}$ at a room temperature, as previously described $(12,13)$. The cells were resuspended in PBS solution and stained with eosin. Cell numbers were counted under a microscope (Olympus MTV-3; Olympus, Tokyo, Japan) using a hemocytometer plate $(12,13)$. For each dish, we took the average of two countings. The cell number was calculated as the number of cells/well of each plate.

Western blot analysis. The RAW267.4 cells (1x10 5 cells/well in $2 \mathrm{ml}$ of medium) were cultured in DMEM containing 10\% FBS and $1 \% \mathrm{P} / \mathrm{S}$ in the presence or absence of either the vehicle $(0.1 \%$ ethanol as a final concentration), $\beta$-caryophyllene $(1 \mu \mathrm{g} / \mathrm{ml}$ of medium), baicalin $(1 \mu \mathrm{g} / \mathrm{ml})$, and/or (+)-catechin $(1 \mu \mathrm{g} / \mathrm{ml})$ for 3 days. In a separate experiment, the cells were cultured in the presence or absence of a combination of $\beta$-caryophyllene $(1 \mu \mathrm{g} / \mathrm{ml})$, baicalin $(1 \mu \mathrm{g} / \mathrm{ml})$ and $(+)$-catechin $(1 \mu \mathrm{g} / \mathrm{ml})$ for 3 days, and then were they cultured for an additional $24 \mathrm{~h}$ with or without the addition of TNF- $\alpha$ (10 ng/ml). Following culture, the cells were washed twice with ice-cold PBS and removed from the dish by scraping in cell lysis buffer containing protein inhibitors. The lysed cells were homogenized by sonication in $0.4 \mathrm{ml}$ of ice-cold cell lyses buffer containing protein inhibitors. The homogenate was centrifuged for $5 \mathrm{~min}$ at 1,500 $\mathrm{x}$ g, and the protein concentration of the supernatant was determined for western blotting using bovine serum albumin as a standard. Samples of supernatant protein $(30 \mu \mathrm{g} /$ lane) were separated by sodium dodecyl sulfate-polyacrylamide gel electrophoresis (SDS-PAGE) and transferred to nylon membranes for western blotting using specific rabbit antibodies against Akt, mitogen-activated protein kinase (MAPK), caspase-3, cyclooxygenase (COX)-1, -2, p65, and $\beta$-actin (all form Cell Signaling Technology, Danvers, MA, USA). $\beta$-actin was used as a loading control. Donkey anti-rabbit IgG-HRP (Santa Cruz Biotechnology, Santa Cruz, CA, USA) was used as the secondary antibody for all the above antibodies. A minimum of 2 blots from independent experiments was scanned on an Epson Perfection 1660 Photo scanner, and bands quantified using ImageJ. Data from independent experiments were normalized to a percentage of control before averaging.

Statistical analysis. Statistical significance was determined using GraphPad InStat version 3 for Windows XP (GraphPad Software Inc., La Jolla, CA, USA). Multiple comparisons were performed by one-way analysis of variance (ANOVA) with Tukey-Kramer multiple comparisons post test for parametric data as indicated. A value of $\mathrm{p}<0.05$ was considered to indicate a statistically significant difference.

\section{Results}

Effects of various botanical molecules on the proliferation of RAW267.4 cells. The effects of various botanical molecules $[\beta$-caryophyllene, baicalin, $(+)$-catechin, curcumin and (+)-aromatic turmerone], which exert anti-inflammatory effects on RAW267.4 cells in vitro have not been investigated thus far. Thus, to determine these effects, the cells were cultured for 3 days in the presence or absence of each compound. The proliferation of the RAW267.4 cells was suppressed in the presence of $\beta$-caryophyllene (50, 100 and $200 \mu \mathrm{g} / \mathrm{ml}$ of medium) (Fig. 1A) or curcumin (100 and $200 \mu \mathrm{g} / \mathrm{ml}$ ) (Fig. 1B). Culture with baicalin $(1,10,50,100$ and $200 \mu \mathrm{g} / \mathrm{ml})$ (Fig. 1C) or (+)-catechin $(1,10,50$, 100 and $200 \mu \mathrm{g} / \mathrm{ml}$ ) (Fig. 1D) did not exert a significant effect on RAW267.4 cell proliferation. Culture with (+)-aromatic turmerone $(25$ and $50 \mu \mathrm{g} / \mathrm{ml})$ significantly increased the proliferation of RAW267.4 cells (data not shown). 

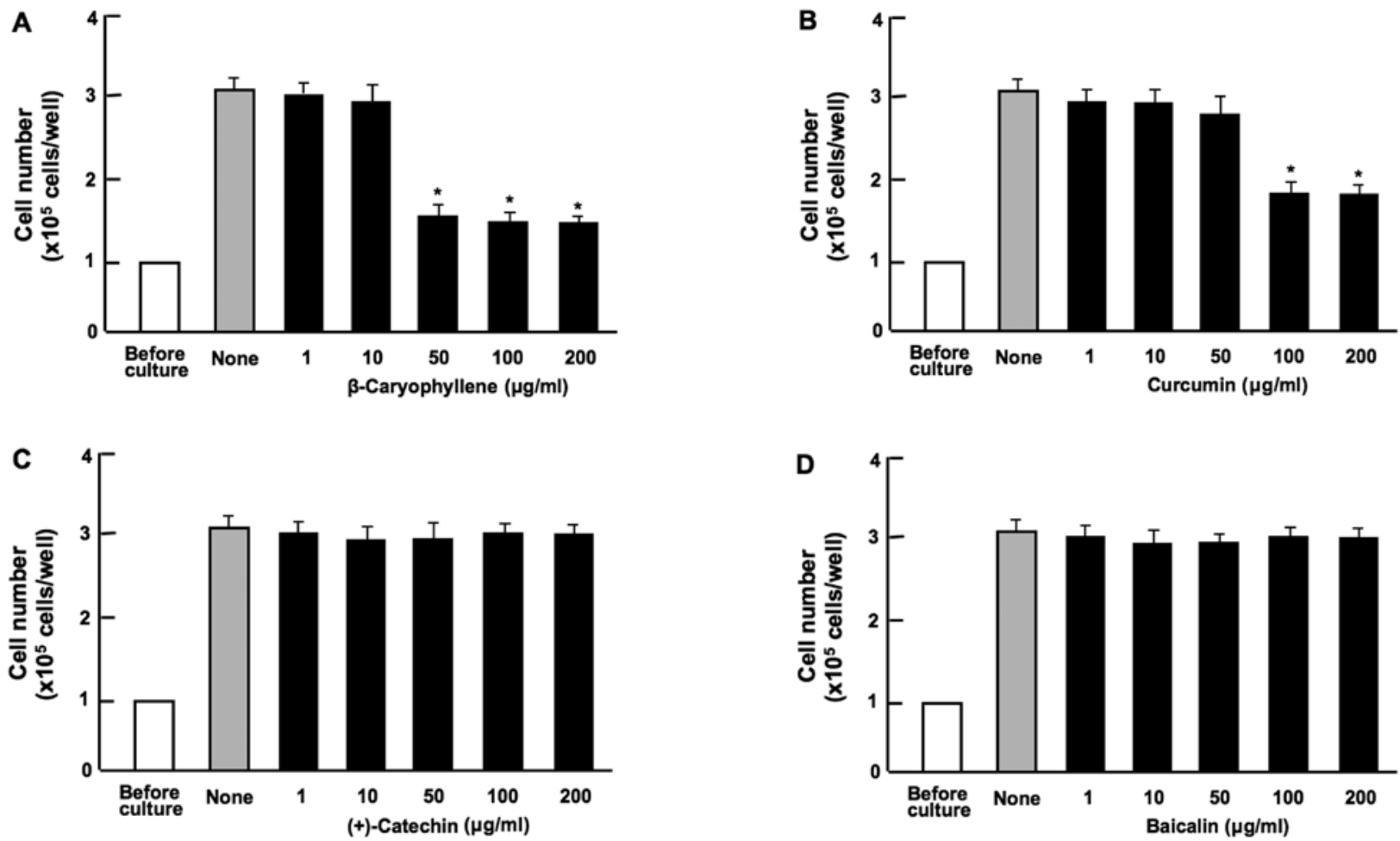

Figure 1. Effects of various botanical molecules on the proliferation of RAW267.4 cells in vitro. RAW267.4 cells were cultured for 3 days in Dulbecco's modification of Eagle's medium (DMEM) containing either the vehicle, $\beta$-caryophyllene [(A) 1, 10, 50, 100 and $200 \mu \mathrm{g} / \mathrm{ml}$ of medium], curcumin [(B) $1,10,50,100$ and $200 \mu \mathrm{g} / \mathrm{ml}],(+)$-catechin [(C) 1, 10,50, 100 and $200 \mu \mathrm{g} / \mathrm{ml}$ ] or baicalin [(D) 1, 10,50, 100 and $200 \mu \mathrm{g} / \mathrm{ml}$ of medium]. Following culture, the number of attached cells on the dish was counted. Data are presented as the means \pm SD of 2 replicate wells/data set using different dishes and cell preparation. ${ }^{*} \mathrm{p}<0.001$ as compared with the control group (grey bar), as shown by one way ANOVA and Tukey-Kramer post-test.
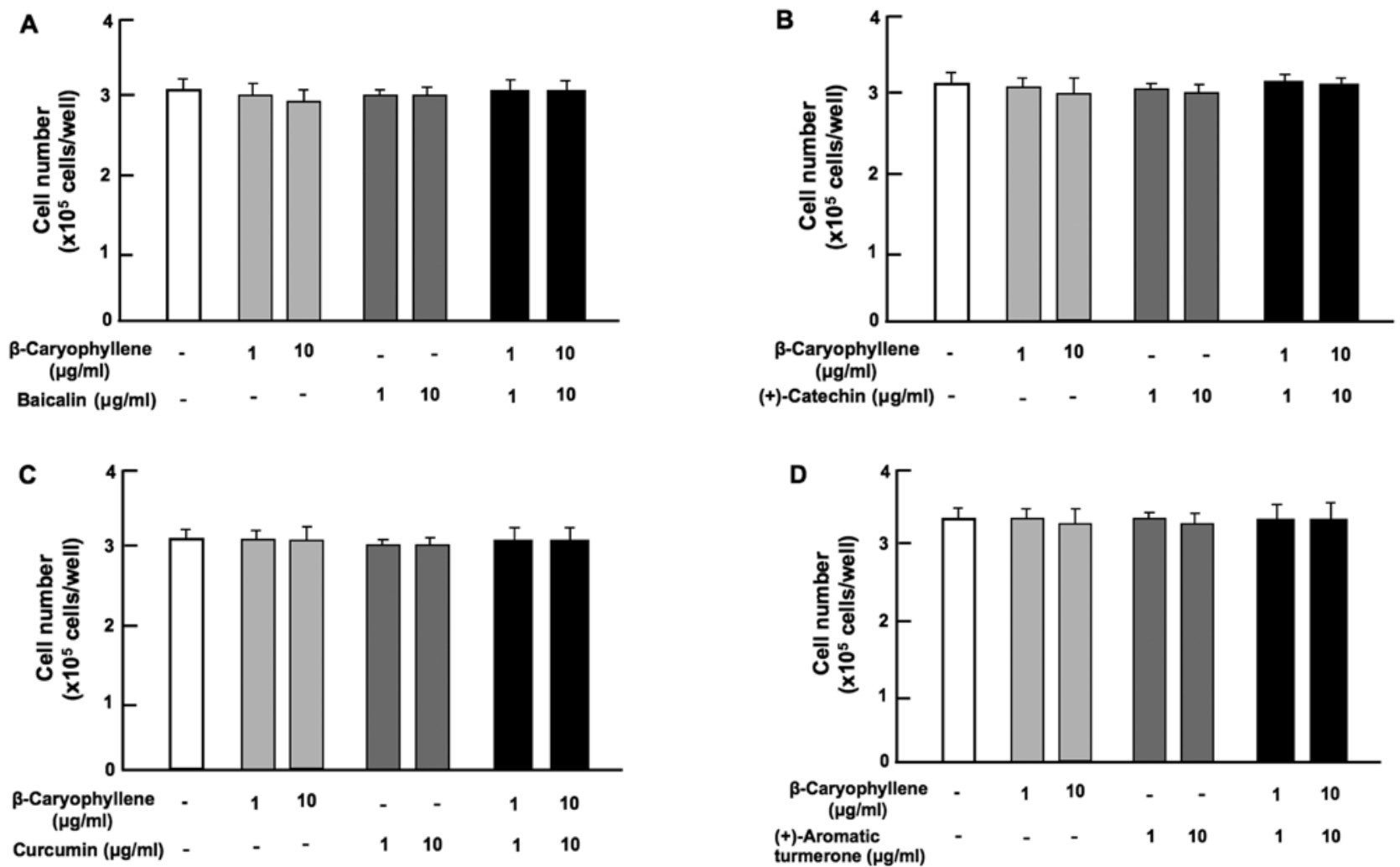

Figure 2. Effects of the combination of $\beta$-caryophyllene with other botanical molecules on the proliferation of RAW267.4 cells in vitro. RAW267.4 cells were cultured for 3 days in Dulbecco's modification of Eagle's medium (DMEM) containing either the vehicle, baicalin [(A) 1 or $10 \mu \mathrm{g} / \mathrm{ml}],(+)$-catechin [(B) 1 or $10 \mu \mathrm{g} / \mathrm{ml}]$, curcumin [(C) 1 or $10 \mu \mathrm{g} / \mathrm{ml}]$ or (+)-aromatic turmerone [(D) 1 or $10 \mu \mathrm{g} / \mathrm{ml}]$ in the presence or absence of $\beta$-caryophyllene $(1 \mathrm{or} 10 \mu \mathrm{g} / \mathrm{ml}$ of medium). Follwoing culture, the number of attached cells on the dish was counted. Data are presented as the means $\pm \mathrm{SD}$ of 2 replicate wells/data set using different dishes and cell preparation. With treatment, no significant difference was observed as compared with the control group (white bar), as shown by one way ANOVA and Tukey-Kramer post-test. 

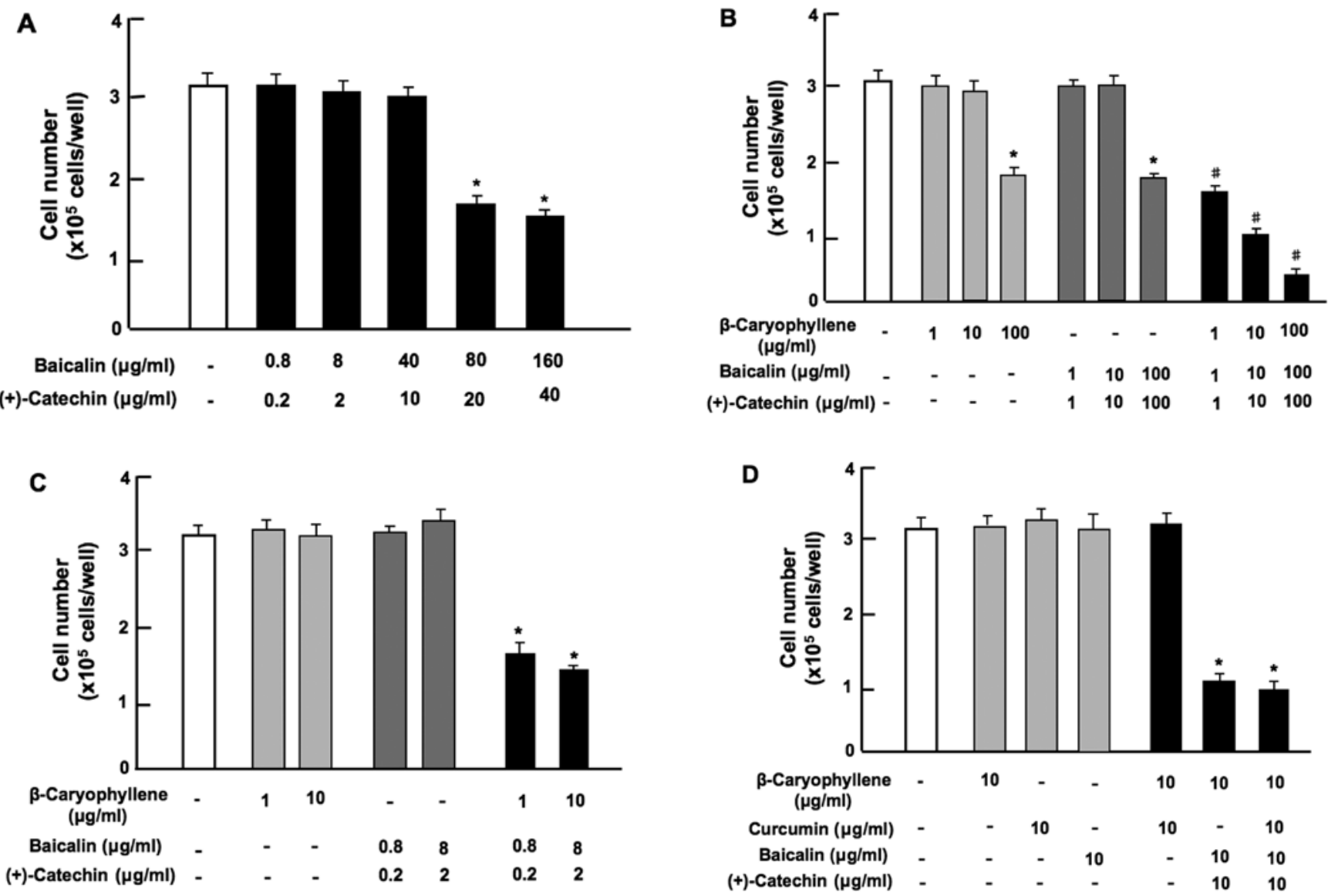

Figure 3. Combination of $\beta$-caryophyllene, (+)-catechin and baicalin exerts a synergistic suppressive effect on the proliferation of RAW267.4 cells in vitro. RAW267.4 cells were cultured for 3 days in Dulbecco's modification of Eagle's medium (DMEM) containing various botanical molecules: (A) both baicalin $(0.8,8,40,80$ and $160 \mu \mathrm{g} / \mathrm{ml}$ of medium) and $/$ or (+)-catechin $(0.2,2,10,20$ and $40 \mu \mathrm{g} / \mathrm{ml})$, (B) baicalin $(1,10$ or $100 \mu \mathrm{g} / \mathrm{ml})$ and $/$ or $(+)$-catechin $(1$ or $10 \mu \mathrm{g} / \mathrm{ml})$ in the presence or absence of $\beta$-caryophyllene $(1,10$ or $100 \mu \mathrm{g} / \mathrm{ml})$, (C) baicalin $(0.8$ or $8 \mu \mathrm{g} / \mathrm{ml})$ and/or (+)-catechin $(0.2$ or $2 \mu \mathrm{g} / \mathrm{ml})$ in the presence or absence of $\beta$-caryophyllene $(1$ or $10 \mu \mathrm{g} / \mathrm{ml})$, (D) curcumin $(10 \mu \mathrm{g} / \mathrm{ml})$, baicalin $(10 \mu \mathrm{g} / \mathrm{ml})$ and $/$ or $(+)$-catechin $(10 \mu \mathrm{g} / \mathrm{ml})$ in the presence or absence of $\beta$-caryophyllene $(10 \mu \mathrm{g} / \mathrm{ml})$. Following culture, the number of attached cells on the dish was counted. Data are presented as the means \pm SD of 2 replicate wells/data set using different dishes and cell preparation. " $\mathrm{p}<0.001$ as compared with the control group (white bar) (A, B, C or D). " $\mathrm{p}<0.001$ as compared with the group (grey bar) treated with baicalin $(1,10$ or $100 \mu \mathrm{g} / \mathrm{ml})$ plus (+)-catechin $(1,10$ or $100 \mu \mathrm{g} / \mathrm{ml})(B)$, as shown by one way ANOVA and Tukey-Kramer post-test.

The combination of $\beta$-caryophyllene, baicalin and $(+)$-catechin exerts a synergistic suppressive effect on the proliferation of RAW267.4 cells. Subsequently, the effects of the combination with various botanical molecules on the proliferation of RAW267.4 cells in vitro were determined. Cell proliferation was not suppressed by the combination of $\beta$-caryophyllene ( 1 or $10 \mu \mathrm{g} / \mathrm{ml})$ with either baicalin (1 or $10 \mu \mathrm{g} / \mathrm{ml})$ (Fig. 2A), (+)-catechin $(1$ or $10 \mu \mathrm{g} / \mathrm{ml}$ ) (Fig. 2B), curcumin (1 or $10 \mu \mathrm{g} / \mathrm{ml}$ ) (Fig. 2C) or (+)-aromatic turmerone (1 and $10 \mu \mathrm{g} / \mathrm{ml})$ (Fig. 2D).

Notably, the combination of baicalin (80 or $160 \mu \mathrm{g} / \mathrm{ml}$ ) and (+)-catechin (20 or $40 \mu \mathrm{g} / \mathrm{ml})$ at comparatively higher concentrations exerted a significant suppressive effect on cell proliferation (Fig. 3A). Moreover, the combination of $\beta$-caryophyllene, baicalin and (+)-catechin at a lower concentration of each $(1$ or $10 \mu \mathrm{g} / \mathrm{ml})$, which did not independently exert a significant effect on cell proliferation, was found to exert a potent synergistic suppressive effect on cell proliferation (Fig. 3B). Such an effect was also observed with a higher concentration $(100 \mu \mathrm{g} / \mathrm{ml})$ of $\beta$-caryophyllene, baicalin and (+)-catechin (Fig. 3B). In addition, the synergistic effects of $\beta$-caryophyllene, baicalin and (+)-catechin on cell proliferation were also observed with the combination of $\beta$-caryophyllene (1 and $10 \mu \mathrm{g} / \mathrm{ml})$, baicalin $(0.8$ or $8 \mu \mathrm{g} / \mathrm{ml})$ and (+)-catechin $(0.2$ or $2 \mu \mathrm{g} / \mathrm{ml}$ ) (Fig. 3C). The synergistic effects observed with the combination of $\beta$-caryophyllene, baicalin and (+)-catechin on cell proliferation were not enhanced in the presence of curcumin $(10 \mu \mathrm{g} / \mathrm{ml})$ (Fig. 3D). Thus, the combination of $\beta$-caryophyllene, baicalin and (+)-catechin was shown to exert a potent synergistic suppressive effect on RAW267.4 cell proliferation in vitro.

Mechanistic characterization of the synergistic suppressive effects of $\beta$-caryophyllene, catechin and baicalin on the proliferation of RAW267.4 cells. The proliferation of the RAW267.4 cells was determined in the presence of various inhibitors that induce cell cycle arrest in vitro (Fig. 4). The cells were cultured for 3 days in the presence of butyrate (10 and $100 \mu \mathrm{M})$, roscovitine (10 and $100 \mathrm{nM})$, or sulforaphane (1 and $10 \mathrm{nM})$. The proliferation of RAW267.4 cells was suppressed in the presence of these inhibitors (Fig. 4A). Such effects were not altered in the cells cultured in the presence of the combination of $\beta$-caryophyllene, catechin and baicalin (Fig. 4B). Thus, the suppressive effects of the combined chemicals on the proliferation of RAW267.4 cells were not altered in the 

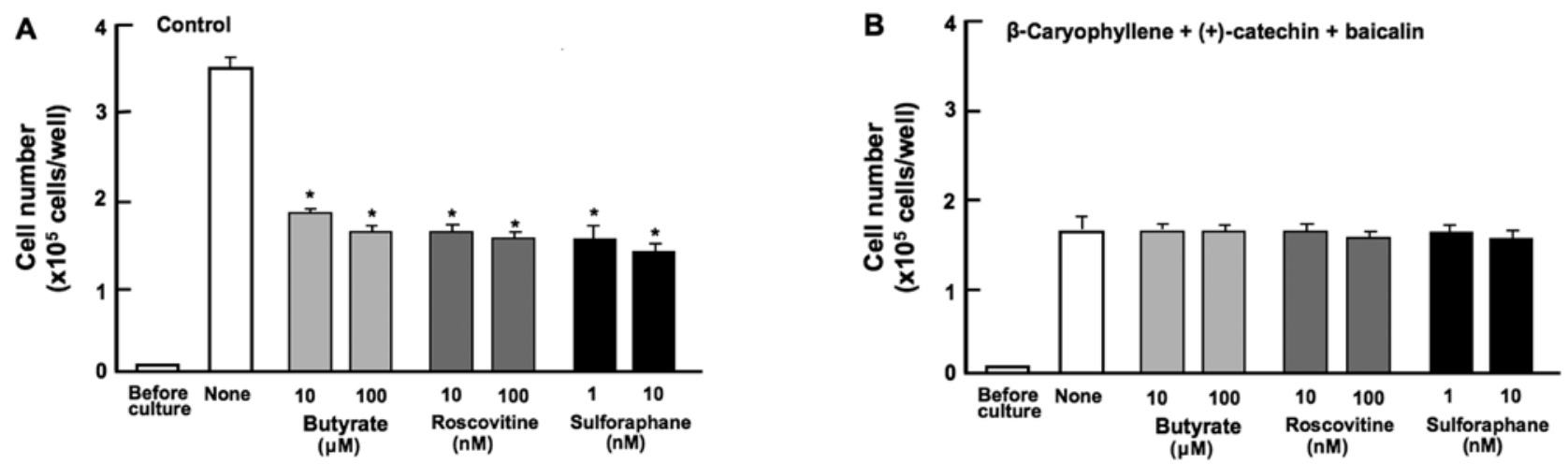

Figure 4. Combination of $\beta$-caryophyllene, (+)-catechin and baicalin on the proliferation of RAW267.4 cells induces cell cycle arrest in vitro. RAW267.4 cells were cultured for 3 days in Dulbecco's modification of Eagle's medium (DMEM) containing either the vehicle [(A) control] or the combination (B) of $\beta$-caryophyllene $(10 \mu \mathrm{g} / \mathrm{ml}$ of medium), baicalin $(10 \mu \mathrm{g} / \mathrm{ml})$ and $(+)$-catechin $(10 \mu \mathrm{g} / \mathrm{ml})$ in the presence or absence of either butyrate $(10$ or $100 \mu \mathrm{M})$, roscovitine $(10 \mathrm{or} 100 \mathrm{nM})$ or sulforaphane $(1 \mathrm{or} 10 \mathrm{nM})$. Follwoing culture, the number of attached cells on the dish was counted. Data are presented as the means \pm SD of 2 replicate wells/data set using different dishes and cell preparation. " $\mathrm{p}<0.001$ as compared with the control group (white bar), as shown by one way ANOVA and Tukey-Kramer post-test.
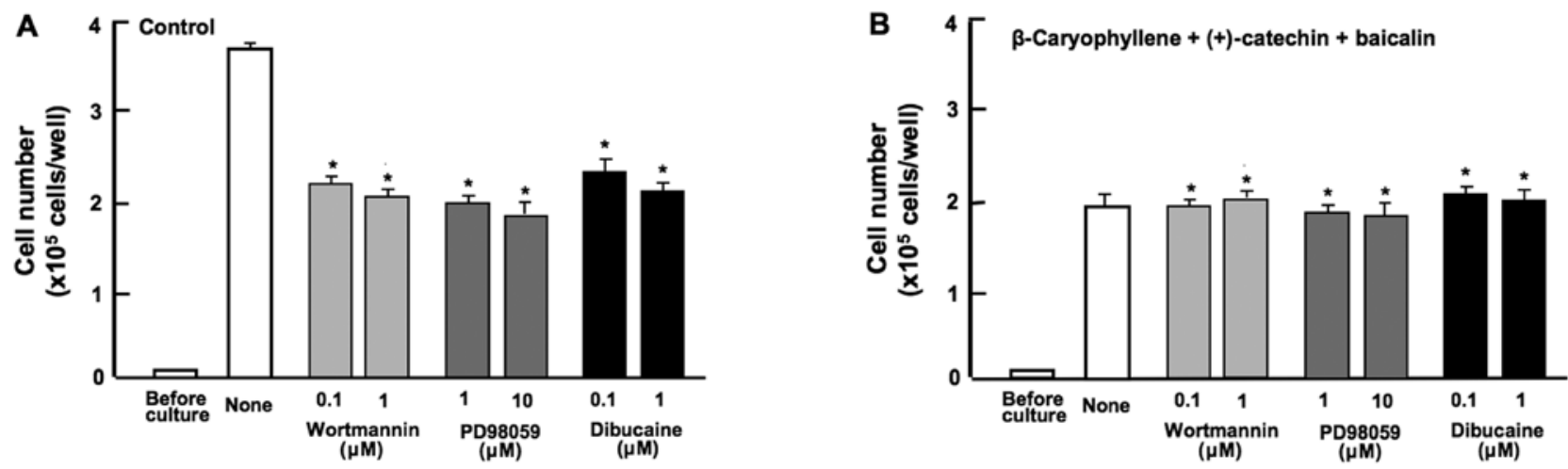

Figure 5. Suppressive effects of the combination of $\beta$-caryophyllene, (+)-catechin and baicalin on the proliferation of RAW267.4 cells are involved in the inhibition of cell signaling pathways in vitro. RAW267.4 cells were cultured for 3 days in Dulbecco's modification of Eagle's medium (DMEM) containing either thevehicle (control) (A) or the mixture (B) of $\beta$-caryophyllene $(10 \mu \mathrm{g} / \mathrm{ml}$ of medium), baicalin $(10 \mu \mathrm{g} / \mathrm{ml})$ and (+)-catechin $(10 \mu \mathrm{g} / \mathrm{ml})$ in the presence or absence of either wortmannin $(0.1$ or $1 \mu \mathrm{M})$, PD98059 $(1$ or $10 \mu \mathrm{M})$ or dibucain $(0.1$ or $1 \mu \mathrm{M})$. Following culture, the number of attached cells on the dish was counted. Data are presented as the means \pm SD of 2 replicate wells/data set using different dishes and cell preparation. ${ }^{*} \mathrm{p}<0.001$ as compared with the control group (white bar), as shown by one way ANOVA and Tukey-Kramer post-test.

presence of butyrate, roscovitine or sulphoraphan, that induce cell cycle arrest. Roscovitine is a potent and selective inhibitor of the cyclin-dependent kinases, cdc2, cdk2m and cdk5 (13). Sulforaphane induces $\mathrm{G} 2 / \mathrm{M}$ phase cell cycle arrest (14). Butyrate inhibits G1 progression (11). In this study, the combined use of the botanical molecules was found to induce G1 and G2/M phase cell cycle arrest in RAW267.4 cells.

Subsequently, to further determine the mechanistic characteristics responsible for the suppressive effects of the combined use of botanical molecules on cell proliferation, we examined whether the suppressive effects of the combined chemicals on the proliferation of RAW267.4 cells are modulated through various signaling factors that suppress cell proliferation. The proliferation of RAW267.4 cells was suppressed in the presence of wortmannin $(0.1$ or $1 \mu \mathrm{M})$, an inhibitor of phosphatidylinositol 3-kinase (PI3K) (15), PD98059 (1 or $10 \mu \mathrm{M})$, an inhibitor of extracellular signal-regulated kinase (ERK) and mitogenactivated protein kinase (MAPK) (16), or dibucaine $(0.1$ or $1 \mu \mathrm{M})$, an inhibitor of $\mathrm{Ca}^{2+} /$ calmodulin-dependent protein kinase (11) (Fig. 5A). The suppressive effects of these inhibitors on cell proliferation were not observed when used in combination with $\beta$-caryophyllene, catechin and baicalin (Fig. 5B).
The combined use of the botanical molecules was found to exert suppressive effects on cell proliferation by inhibiting various intracellular signaling pathways, such as the PI3K/Akt, ERK/MAPK and $\mathrm{Ca}^{2+}$ pathways in RAW267.4 cells.

Combination of $\beta$-caryophyllene, baicalin and (+)-catechin promotes the death of RAW267.4 cells in vitro. To determine whether the combination of $\beta$-caryophyllene, baicalin and (+)-catechin induces apoptotic cell death in vitro, RAW267.4 cells were cultured for 3 days until they reached confluence, and the cells were then cultured for an additional 2 days in the presence or absence of either $\beta$-caryophyllene $(10 \mu \mathrm{g} / \mathrm{ml})$, baicalin $(10 \mu \mathrm{g} / \mathrm{ml})$, or $(+)$-catechin $(10 \mu \mathrm{g} / \mathrm{ml})$ with or without caspase-3 inhibitor $(10 \mu \mathrm{M})$ (Fig. 6). The addition of $\beta$-caryophyllene, baicalin or (+)-catechin alone did not cause a significant alteration in the number of RAW267.4 cells (Fig. 6A). However, the combination of $\beta$-caryophyllene $(10 \mu \mathrm{g} / \mathrm{ml})$, baicalin $(10 \mu \mathrm{g} / \mathrm{ml})$ and $(+)$-catechin $(10 \mu \mathrm{g} / \mathrm{ml})$ caused a significant decrease in cell number, indicating that this treatment induces cell death. Culture with curcumin $(10 \mu \mathrm{g} / \mathrm{ml})$ did not exert an effect on cell death (Fig. 6A). Of note, the suppressive effects of combination of the botanical molecules on cell death were completely 
A

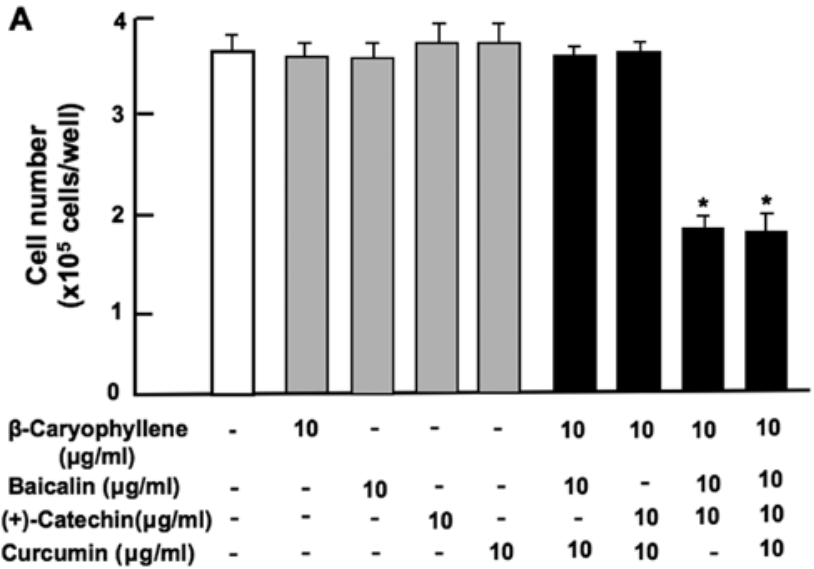

B

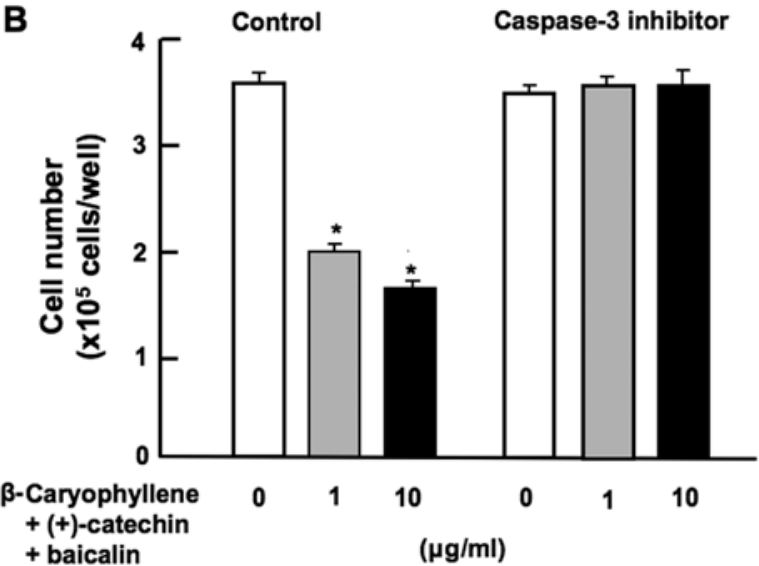

Figure 6. Combination of $\beta$-caryophyllene, baicalin and (+)-catechin exerts a synergistic promoting effect on the death of RAW267.4 cells in vitro. RAW267.4 cells were cultured for 3 days without various botanical molecules, and then the cells with subconfluency were additionally cultured for 2 days in Dulbecco's modification of Eagle's medium (DMEM) containing either baicalin (1 or $10 \mu \mathrm{g} / \mathrm{ml}$ of medium) plus $(+)$-catechin $(1 \mathrm{or} 10 \mu \mathrm{g} / \mathrm{ml})$ in the presence or absence of $\beta$-caryophyllene ( 1 or $10 \mu \mathrm{g} / \mathrm{ml})$ without caspase-3 (A) or with caspase-3 inhibitor $(10 \mu \mathrm{M})(\mathrm{B})$. Following culture, the number of attached cells on dish was counted. Data are presented as the means \pm SD of 2 replicate wells/data set using different dishes and cell preparation. "p $<0.001$ as compared with the control group (white bar), as shown by one way ANOVA and Tukey-Kramer post-test.
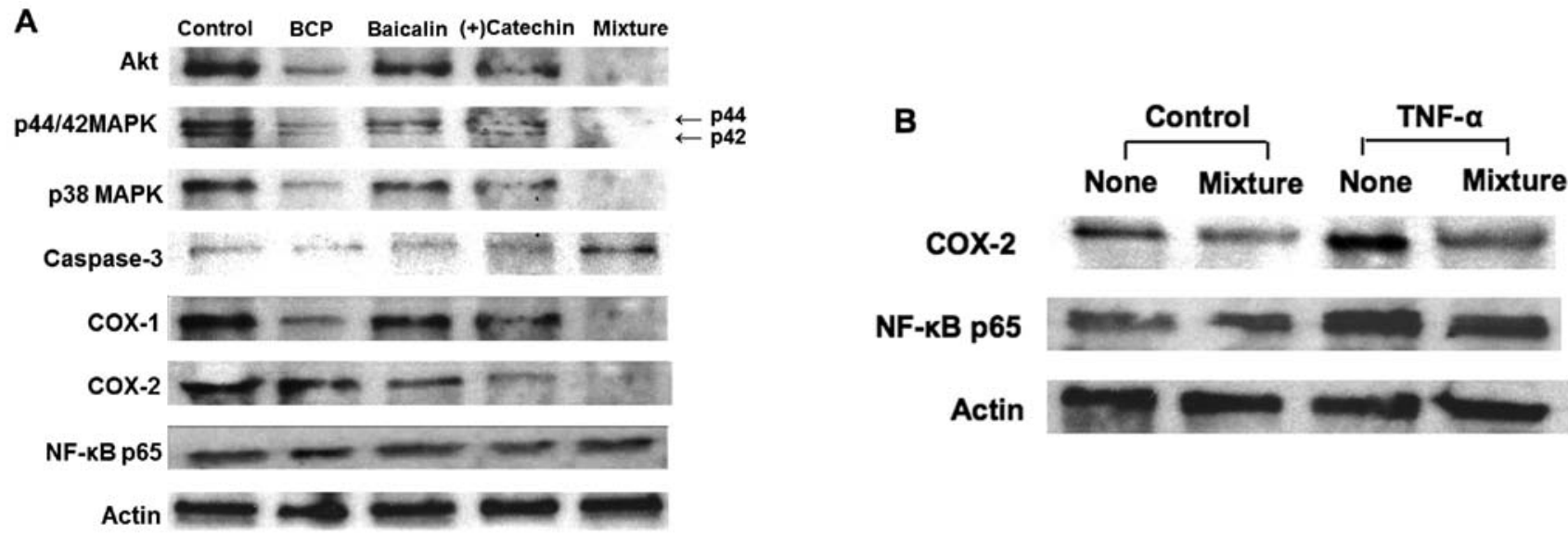

Figure 7. Effects of $\beta$-caryophyllene, baicalin and (+)-catechin on levels of protein related to proliferation, apoptosis and inflammation in RAW267.4 cells in vitro. (A) RAW267.4 cells were cultured for 3 days in Dulbecco's modification of Eagle's medium (DMEM) containing either the vehicle or a combination of $\beta$-caryophyllene $(1 \mu \mathrm{g} / \mathrm{ml}$ of medium), baicalin $(1 \mu \mathrm{g} / \mathrm{ml})$ and $(+)$-catechin $(1 \mu \mathrm{g} / \mathrm{ml})$. (B) RAW267.4 cells were cultured for 3 days in the presence or absence of combined $\beta$-caryophyllene $(1 \mu \mathrm{g} / \mathrm{ml})$, baicalin $(1 \mu \mathrm{g} / \mathrm{ml})$ and $(+)$-catechin $(1 \mu \mathrm{g} / \mathrm{ml})$, and cells reached subconfluence were additionally cultured for $24 \mathrm{~h}$ in the presence of either with or without tumor necrosis factor (TNF)- $\alpha(10 \mathrm{ng} / \mathrm{ml}$ of medium). Following culture, the cells were removed from the dish with a cell scraper after cell lysis buffer containing protein inhibitors. Samples (30 $\mu \mathrm{g})$ of supernatant protein/lane were separated by sodium dodecyl sulfatepolyacrylamide gel electrophoresis (SDS-PAGE) and transferred to nylon membranes for western blotting using antibodies against various proteins. The figure shows the effects of the combined use of $\beta$-caryophyllene, baicalin and (+)-catechin without (A) or with (B) TNF- $\alpha$. Data are presented as a data set using the cell preparation obtained from different dishes with replicates.

prevented in the presence of caspase-3 inhibitor (Fig. 6B). These results suggest that the combined use of the botanical molecules induce cell death related to caspase-3, that activates nuclear DNA fragmentation, which induces apoptotic cell death (17).

Effects of $\beta$-caryophyllene, baicalin and (+)-catechinonvarious protein levels in RAW267.4 cells. Alterations in the expression of key proteins related to cell proliferation, apoptotic cell death and inflammation were examined by western blot analysis (Fig. 7). The combination of $\beta$-caryophyllene (1 or $10 \mu \mathrm{g} / \mathrm{ml})$, baicalin (1 or $10 \mu \mathrm{g} / \mathrm{ml})$ and (+)-catechin (1 or $10 \mu \mathrm{g} / \mathrm{ml})$ exerted a suppressive effect on Akt, p44/42 MAPK, p38 MAPK and COX-1 and -2 expression (Fig. 7A). Culture with this combination increased caspase- 3 expression, but did not alter the levels of nuclear factor- $\mathrm{kB}(\mathrm{NF}-\kappa \mathrm{B})$ p65 (Fig. 7A). Moreover, culture with TNF- $\alpha(10 \mathrm{ng} / \mathrm{ml})$ caused an increase in COX-2 and NF- $\kappa$ B p65 expression (Fig. 7B). This effect was suppressed by the combination of $\beta$-caryophyllene, baicalin and (+)-catechin at the concentration of $1 \mu \mathrm{g} / \mathrm{ml}$ (Fig. 7B).

\section{Discussion}

$\beta$-caryophyllene is a cannabinoid receptor 2 agonist, which exerts anti-inflammatory effects (1-5). This study was undertaken to determine the effects of $\beta$-caryophyllene and other herbal molecules, which exert antioxidant and anti-inflammatory effects on mouse RAW267.4 macrophages in vitro. Of note, we found that the combined use of the three botanical molecules [ $\beta$-caryophyllene, baicalin and ( + -)-catechin] at comparatively lower concentrations, which alone did not exert 
any effects on cell proliferation, exerted a potent synergisticsuppressive effect on the proliferation of RAW267.4 cells in vitro. These synergistic effects may provide a useful pharmacologic tool for managing inflammatory pain.

Mechanistically, the combination of $\beta$-caryophyllene, baicalin and (+)-catechin was found to induce G2/M phase cell cycle arrest in RAW267.4 cells using various inhibitors that induce cell cycle arrest in vitro. Moreover, the combined use of the botanical molecules exerted suppressive effects on cell proliferation by inhibiting various intracellular signaling pathways, such as the PI3K/Akt, ERK/MAPK and $\mathrm{Ca}^{2+}$ pathways in RAW267.4 cells, using various inhibitors (11,13-16). In addition, the combined use of the three agents was found to decrease the protein levels of Akt and MAPKs (p44/42 and p38) in RAW267.4 cells.

$\beta$-caryophyllene, baicalin and (+)-catechin did not, individually, exert a significant effect on the death of RAW267.4 cells in vitro. Importantly, the combination of $\beta$-caryophyllene, baicalin and (+)-catechin at comparatively lower concentrations of each agent was found to promote the death of RAW267.4 cells in vitro. This finding suggests that the suppressive effects on the proliferation of RAW267.4 cells exerted by the combined use of $\beta$-caryophyllene, baicalin and (+)-catechin, may be partly dependent on a promoting effect on cell death. Mechanistically, suppressive effects of the combined use of the botanical molecules on cell death were completely prevented in the presence of caspase-3 inhibitor. In addition, the combined use of the three agents increased caspase-3 expression in RAW267.4 cells. These findings suggest that the cell death induced by the combined use of the three botanical molecules is related to the activation of caspase-3, that activates nuclear DNA fragmentation, which induces apoptotic cell death (17).

Whether or not the combined effect of $\beta$-caryophyllene, baicalin and (+)-catechin on the proliferation and death of RAW267.4 cells influences inflammatory conditions, is unknown. However, we found that the combination of $\beta$-caryophyllene, baicalin and (+)-catechin decreased COX-1 and COX-2 expression in RAW267.4 cells in vitro. Inflammation-inducing factors have been reported to increase COX-2 and NF- $\mathrm{kB}$ p65 expression, which is related to MAPK signaling pathways (18-21). Furthermore, we found that the TNF- $\alpha$-induced increased in the COX-2 and NF- $\kappa B$ p65 levels was suppressed by culture with the combination of the botanical molecules. These findings support the view that the combination of $\beta$-caryophyllene, baicalin and (+)-catechin exerts potent inhibitory effects on the inflammatory condition related to the function of activated macrophages.

In conclusion, this study demonstrates that a composition of botanical molecules, including $\beta$-caryophyllene, baicalin and (+)-catechin at comparatively low levels exerts potential synergistic suppressive effects on the function of macrophages related to inflammation. This composition may prove to be usefule as a novel anti-inflammatory therapy.

\section{References}

1. Ghelardini C, Galeotti N, Di Cesare Mannelli L, Mazzanti G and Bartolini A: Local anaesthetic activity of beta-caryophyllene. Farmaco 56: 387-389, 2001.

2. Gertsch J, Leonti M, Raduner S, Racz I, Chen JZ, Xie XQ, Altmann KH, Karsak M and Zimmer A: Beta-caryophyllene is a dietary cannabinoid. Proc Natl Acad Sci USA 105: 9099-9104, 2008.
3. Ormeño E, Baldy V, Ballini C and Fernandez C: Production and diversity of volatile terpenes from plants on calcareous and siliceous soils: Effect of soil nutrients. J Chem Ecol 34: 1219-1229, 2008

4. Katsuyama S, Mizoguchi H, Kuwahata H, Komatsu T, Nagaoka K, Nakamura H, Bagetta G, Sakurada T and Sakurada S: Involvement of peripheral cannabinoid and opioid receptors in $\beta$-caryophyllene-induced antinociception. Eur J Pain 17: 664-675, 2013.

5. Paula-Freire LI, Andersen ML, Gama VS, Molska GR and Carlini EL: The oral administration of trans-caryophyllene attenuates acute and chronic pain in mice. Phytomedicine 21: 356-362, 2014

6. Chavan MJ, Wakte PS and Shinde DB: Analgesic and antiinflammatory activity of Caryophyllene oxide from Annona squamosa L. bark. Phytomedicine 17: 149-151, 2010.

7. Martinez RM, Zarpelon AC, Cardoso RD, Vicentini FT, Georgetti SR, Baracat MM, Andrei CC, Moreira IC, Verri WA Jr and Casagrande R: Tephrosia sinapou ethyl acetate extract inhibits inflammatory pain in mice: Opioid receptor dependent inhibition of TNF $\alpha$ and IL-1 $\beta$ production. Pharm Biol 51: 1262-1271, 2013.

8. Pomari E, Stefanon B and Colitti M: Effect of plant extracts on $\mathrm{H}_{2} \mathrm{O}_{2}$-induced inflammatory gene expression in macrophages. J Inflamm Res 7: 103-112, 2014.

9. Yamaguchi M, Vikulina T, Arbiser JL and Weitzmann MN: Suppression of NF- $\kappa \mathrm{B}$ activation by gentian violet promotes osteoblastogenesis and suppresses osteoclastogenesis. Curr Mol Med 14: 783-792, 2014.

10. Yamaguchi M and Weitzmann MN: The bone anabolic carotenoid p-hydroxycinnamic acid promotes osteoblast mineralization and suppresses osteoclast differentiation by antagonizing NF- $\mathrm{B}$ activation. Int J Mol Med 30: 708-712, 2012.

11. Yamaguchi $M$ and Daimon Y: Overexpression of regucalcin suppresses cell proliferation in cloned rat hepatoma H4-II-E cells: Involvement of intracellular signaling factors and cell cycle-related genes. J Cell Biochem 95: 1169-1177, 2005.

12. Izumi $\mathrm{T}$ and Yamaguchi $\mathrm{M}$ : Overexpression of regucalcin suppresses cell death in cloned rat hepatoma H4-II-E cells induced by tumor necrosis factor-alpha or thapsigargin. J Cell Biochem 92: 296-306, 2004.

13. Meijer L, Borgne A, Mulner O, Chong JP, Blow JJ, Inagaki N, Inagaki M, Deleros JG and Moulinoux JP: Biochemical and cellular effects of roscovitine, a potent and selective inhibitor of the cyclin-dependent kinases cdc2, cdk2 and cdk5. Eur J Biochem 243: 527-536, 1997.

14. Singh SV, Herman-Antosiewicz A, Singh AV, Lew KL, Srivastava SK, Kamath R, Brown KD, Zhang L and Baskaran R: Sulforaphane-induced G2/M phase cell cycle arrest involves checkpoint kinase 2-mediated phosphorylation of cell division cycle 25C. J Biol Chem 279: 25813-25822, 2004.

15. Serrano-Nascimento C, da Silva Teixeira S, Nicola JP, Nachbar RT, Masini-Repiso AM and Nunes MT: The acute inhibitory effect of iodide excess on sodium/iodide symporter expression and activity involves the PI3K/Akt signaling pathway. Endocrinology 155: 1145-1156, 2014.

16. Chen S, Wang Y, Ruan W, Wang X and Pan C: Reversing multidrug resistance in hepatocellular carcinoma cells by inhibiting extracellular signal-regulated kinase/mitogen-activated protein kinase signaling pathway activity. Oncol Lett 8: 2333-2339, 2014.

17. Zhao Y, Jing Z, Li Y and Mao W: Berberine in combination with cisplatin suppresses breast cancer cell growth through induction of DNA breaks and caspase-3-dependent apoptosis. Oncol Rep 36: 567-572, 2016.

18. Echizen K, Hirose O, Maeda Y and Oshima M: Inflammation in gastric cancer: Interplay of the COX-2/prostaglandin $\mathrm{E}_{2}$ and Toll-like receptor/MyD88 pathways. Cancer Sci 107: 391-397, 2016.

19. Lin CC, Chan CM, Huang YP, Hsu SH, Huang CL and Tsai SJ: Methylglyoxal activates NF- $\kappa$ B nuclear translocation and induces COX-2 expression via a p38-dependent pathway in synovial cells. Life Sci 149: 25-33, 2016.

20. Li N, Liu BW, Ren WZ Liu JX, Li SN, Fu SP, Zeng YL, Xu SY, Yan X, Gao YJ, Liu DF and Wang W: GLP-2 attenuates LPS-induced inflammation in BV-2 cells by inhibiting ERK1/2, JNK1/2 and NF- $\kappa$ B signaling pathway. Int J Mol Sci 17: E190, 2016.

21. Cha SM,Cha JD,Jang EJ,Kim GU and Lee KY: Sophoraflavanone G prevents Streptococcus mutans surface antigen I/II-induced production of $\mathrm{NO}$ and $\mathrm{PGE}_{2}$ by inhibiting MAPK-mediated pathways in RAW 264.7 macrophages. Arch Oral Biol 68: 97-104, 2016. 